\title{
Molecular characterization and phylogenetic analysis of Escherichia coli isolated from milk of cattle affected by mastitis
}

\author{
A.A. Neamah ${ }^{\circledR}$, K.H. Fahed ${ }^{\circledR}$, J.N. Sadeq ${ }^{\circledR}$ and M.A. Alfatlawi \\ Department of Veterinary Microbiology, College of Veterinary Medicine, University of Al-Qadisiyah, Al-Diwaniyah, Iraq
}

Article information

\section{Article history:}

Received April 11, 2021

Accepted May 20, 2021

Available online December 20, 2021

\section{Keywords:}

E. coli

Mastitis

Phylogenetic tree

Cattle milk

PCR

\section{Correspondence:}

M.A. Alfatlawi

monyerr.abd@qu.edu.iq

\begin{abstract}
This evolution-based study aimed to reliably identify the epidemiological prevalence of Escherichia coli that was recovered from affected milk of cattle by mastitis, study the evolution of this bacterium, and describe some isolates using polymerase chain reaction (PCR) technique and DNA sequencing. Here, we collected 50 cattle milk samples and submitted them to conventional bacterial isolation and identification using enrichment culture method and biochemical tests. Then, we confirmed the results by PCR technique based on 16S ribosomal RNA gene. The results showed that E. coli was isolated from cattle at $(36 \%)$, and this was confirmed by PCR that showed highly specific detection of E. coli isolates at (100\%). DNA sequencing of partial 16S ribosomal RNA gene showed (99\%) homological identity with NCBI-Blast $E$. coli isolates and the phylogenetic analysis showed genetic similarity ( 0.5 genetic changes). In conclusion, this was the first study in Iraq to report genetic relationship between $E$. coli isolated from milk of mastitis-infected cattle. Therefore, it is essential to define the role of animals as an important source in the distribution of some pathogens that are related to public health.
\end{abstract}

DOI: 10.33899/ijvs.2021.129934.1702, (CAuthors, 2022, College of Veterinary Medicine, University of Mosul.

This is an open access article under the CC BY 4.0 license (http://creativecommons.org/licenses/by/4.0/).

\section{Introduction}

Mastitis is considered as a devastating health problem in dairy animals. The condition is a global issue that affects milk-producing animals around the world leaving important economic crises in countries that relies on dairy production $(1,2)$. This disease condition is characterized by inflammation of mammary gland tissues that is caused by various inflammation inducers such as bacteria and viruses (3). This illness generates multiple problems such as animal health, economic, and even milk quality problem especially when dairy cattle undergo an apparent mastitis such as subclinical mastitis (4).

The disease condition is predisposed via different reasons such as hygiene, management, and milking process errors. Precautionary criteria such as cleaning and disinfecting teats of dairy cattle before milking are important in limiting the occurrence of new infections of mastitis (5). Moreover, mastitis is presented via losses in milk production at $49 \%$ and veterinarian services at $37 \%$ of total losses (6). When the disease condition is predisposed, causative agents such as bacteria induce mastitis in different stages of peracute, acute, subacute, and chronic levels. Wide range of bacteria that cause inflammation to the mammary gland tissues is presented by both Gram positive and negative. However, certain groups of bacteria play important roles in these infections such as Staphylococcus spp and Escherichia coli (7).

In some cases, E. coli represents the most influential bacterium that causes clinical mastitis (8). The current study was focused on the molecular identification of $E$. coli in the affected mammary glands with mastitis in cattle. Molecular detection of $E$. coli by PCR technique has led to rapid, very sensitive detection of $E$. coli from food samples and samples from clinical test. Many types of food have PCR inhibitors, which effect on purification of the target DNA, so sampling requiring enough samples prepare to eliminate or inactivation inhibitors before PCR test 
(amplification). The very low level of E. coli in many cases in food samples, lead to amplification step of it treats the low sensitivity, so that make the time to complete the test need at least 24 hours. So that a very sensitive, specific and very rapid test need to isolate and detect $E$. coli we need to find (9).

This study was intended to further understanding the evolutionary history of this bacterium in the Al-Diwaniyah City, Iraq.

\section{Materials and methods}

\section{Sampling}

Milk was sampled from cattle apparently suffered from mastitis that had been identified via California-mastitis test (CMT) from different locations in Al-Diwaniyah City. The milk of each sample was poured into $25 \mathrm{ml}$ sterile containers.

The milk was collected after cleaning and washing the quarters of udders by disinfectant solution. After that, the milk samples were transported into laboratory and stored in a $4^{\circ} \mathrm{C}$ until use for bacterial isolation.

\section{Bacterial isolation}

First, the milk samples were inoculated onto brain heartbased infusion-broth and were left in an incubator for $18 \mathrm{hrs}$. Second, the resulted growth was cultivated in EMBbased agar and blood-based agar and was left in an incubator for $18 \mathrm{hrs}$.

\section{Extraction of DNA and PCR}

To detect $E$. coli isolates via the use of PCR targeting a specific sequence region in the $16 S$ rRNA gene, the following steps were followed. First, bacteria were exposed to DNA extraction using Presto Mini-DNA Bacteria Kit (Geneaid Biotech Ltd. USA).

The manufacturer's instructions were followed that included making $11 \mathrm{mg} / \mathrm{ml}$ proteinase $\mathrm{k}$ buffer. Second, the extracted DNA was evaluated using NanoDrop to check for its quality and quantity. Primers were designed using NCBI Websites and Primer 3 Plus software. The resulted primers were F: GGAACTGAGACACGGTCCAG and R: CGTCAGTCTTCGTCCAGGG. They targeted a specific region, $438 \mathrm{bp}$, in the studied gene. These primers were purchased from Bioneer Company, Korea.

The master mix was generated using Accu-Power ${ }^{\circledR}$ PCR-PreMix-Kit and following the kit instruction. Amounts of $2.5 \mu \mathrm{l}$ DNA, $1.25 \mu 1$ from each primer, and $15 \mu 1$ water for molecular use. The mix was placed in the kit specific tube that contains polymerase, dNTPs, and buffer. The mixes were then vortexed for 3 minutes. Finally, the tubes were transferred to a thermocycler (T100 Thermal cycler BioRad. USA) in which the conditions were 1 cycle of first DNA-based denaturation at $95^{\circ} \mathrm{C} 5 \mathrm{~min}, 30$ cycles of (DNA-based denaturation at $95^{\circ} \mathrm{C} 30 \mathrm{~s}$, DNA annealing at $58^{\circ} \mathrm{C} 30$ s, and DNA-based extension at $\left.72^{\circ} \mathrm{C} 1 \mathrm{~min}\right)$, and 1 cycle of finishing extension at $72^{\circ} \mathrm{C} 5 \mathrm{~min}$ (According to the primer manufacturer's instructions).

The resulted PCR-based products were examined using $1 \%$ gel electrophoresis with the use of ethidium bromide and investigated under UV imager.

\section{$16 S$ rRNA gene partial sequencing}

The PCR-based product was recovered from the used gel via the use of (EZ EZ-10 Spin Column DNA Gel Extraction Kit, Biobasic, Canada).

The resulted samples were sent to sequencing (Macrogen, Korea). The phylogenetic tree was built utilizing the UPGMA-based method, MEGA 6.0.

\section{Results}

\section{Cultivation and PCR}

E. coli isolation results were $18(36 \%)$ positive out of 50 samples. PCR confirmation of the resulted isolates was successfully generated using the primers that targeted a 438 bp region in the $16 \mathrm{~S}$ rRNA gene in the E. coli (Figure $1)$.

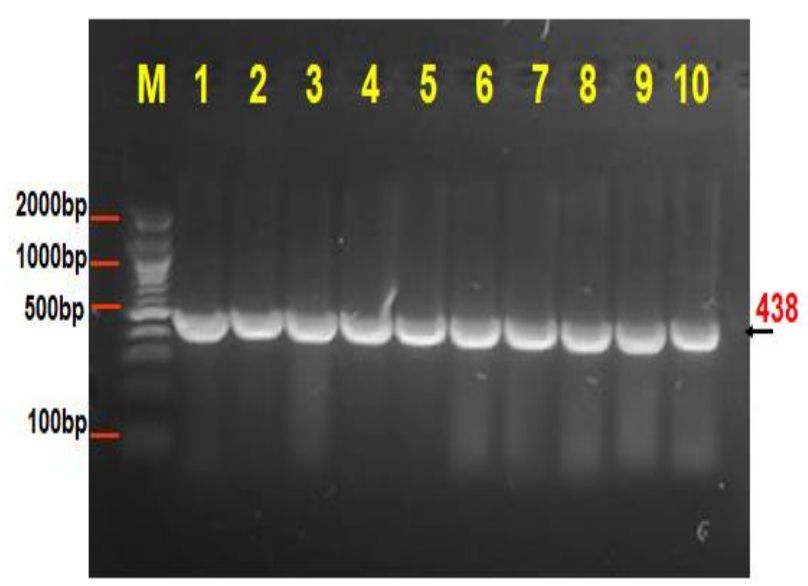

Figure 1: PCR-based gel electrophoresis. The $16 S$ rRNAbased amplification in $E$. coli isolates from mastitis infected milk. Lane (M) represents the DNA marker (2000-100bp), Lane (1-10) show 10 positive samples at $438 \mathrm{bp}$-size of amplification.

\section{DNA Sequencing analysis results}

The results regarding the DNA sequencing further confirmed the identity of the causative agent, E. coli, which induced mastitis in the affected dairy cattle.

The current study isolates, when phylogenetic analysis was done, showed homological sequence identity with global isolates at $99 \%$ matching rate and which shown as phylogenetic tree (Figure 2). 


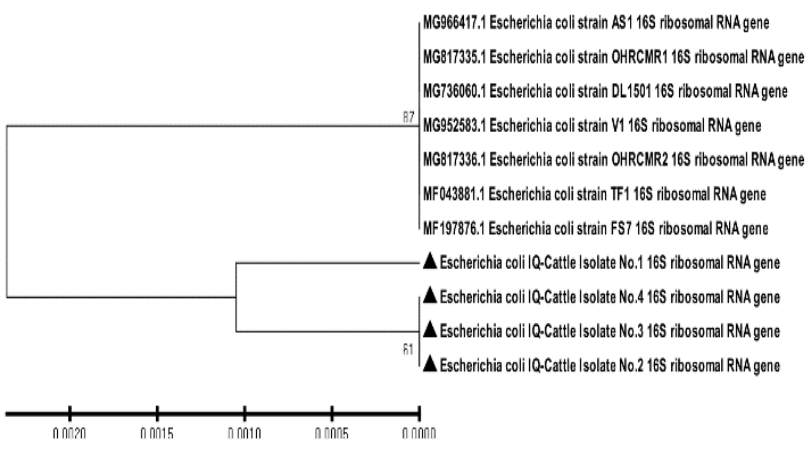

Figure 2: Phylogenetic tree targeting $16 S$ rRNA. The isolates have $99 \%$ identity with global $E$. coli isolates.

\section{Discussion}

The condition, Mastitis, is manifested by the inflammation-based effects of udder gland tissues, and it still represents among the most major health problems that affect cattle around the world. The disease condition causes huge losses in various aspects of dairy industries from health of affected animals, losses in the veterinary services, and to the reduced quality and quantity of the produced milk (10-13). This illness is caused by various bacterial and viral agents such as Staph. aureus, Streptococcus agalactiae, and E. coli (14). The current study was focused on the common causative agent, E. coli, which influences cattle udder glands causing mastitis. Such attention to this microorganism was made to study the evolution of this bacterium in the affected cattle in Al-Diwaniyah City, Iraq. Consistent with other previously made studies (15-17), our results showed the presence of this bacterium in an important rate, $36 \%$, in the milk of the affected cattle. The PCR showed high ability to identify the causative agent in this study. This agrees with Gianneechini et al. (11) who detected, using $16 S$ rRNA gene-based PCR method, E. coli as a leading inducing bacteria for mastitis. The results of the partial sequencing targeting a specific region in the $16 \mathrm{~S}$ rRNA gene showed the reliability of the used method to correctly identifying the presence of $E$. coli in the affected cattle in the current study and showed close relationship to certain isolates of this bacterium from the world. The $99 \%$ identity presented in this study may indicate tiny nucleotide differences between our isolates and the world bacteria. This also indicates that these bacteria in the current study might have suffered certain deleterious mutations that led to such differences in the nucleotide sequences. This result matches with previously works which identified that these bacteria may arise from the environment contaminated with gut bacteria (18-21). This study confirms the E. coli-based infection in the tested milk of the affected cattle in the studied city, and it provides valued information about the trusted use of methodology in detecting the causative agents that infect mammary glands of dairy animals.

\section{Conclusion}

This was the first study in Iraq to report genetic relationship between $E$. coli isolated from milk of mastitisinfected cattle, and it is essential to define the role of animals as an important source in the distribution of some pathogens that are related to public health.

\section{Acknowledgments}

The authors thank Professor Jabbar A. Alssady, Dean of College of Veterinary Medicine, University of AlQadisiyah, Iraq, for technical assistance.

\section{Conflict of interests}

The authors have not received any funding or benefits from industry, agency of financing, or elsewhere to conduct this study.

\section{References}

1. Kumar DRA, Chakraborty S, Verma AK, Tiwari R, Dhama K, Singh U, Kumar S. Trends in diagnosis and control of bovine mastitis: a review. Pakistan J Biol Sci PJBS. 2013;16(23):1653-1661. DOI: 10.3923/pjbs.2013.1653.1661

2. Hillerton JE, Berry EA. Treating mastitis in the cow: A tradition or an archaism. J Appl Microbiol. 2005;98(6):1250-1255. DOI: 10.1111/j.1365-2672.2005.02649.x

3. McDougall S. Bovine mastitis: epidemiology, treatment and control. New Zeeland Vet J. 2002;50(sup3):81-84. DOI: 10.1080/00480169.2002.36274

4. Hiitio H, Vakkamaki J, Simojoki H, Auto T, Junnila J, Pelkonen S, Pyorala S. Prevalence of subclinical mastitis in Finnish dairy cows: changes during recent decades and impact of cow and herd factors. Acta Vet Scand. 2017;59(1):22. DOI: 10.1186/s13028-017-0288-x

5. Gleeson D, Flynn J, Brien BO. Effect of pre-milking teat disinfection on new mastitis infection rates of dairy cows. Iranian Vet $\mathrm{J}$. 2018;71(1):11. DOI: 10.1186/s13620-018-0122-4

6. Sinha MK, Thombare NN, Mondal B. Subclinical mastitis in dairy animals: Incidence, economics, and predisposing factors. Sci World J. 2014;20(2):523984. DOI: $10.1155 / 2014 / 523984$

7. Naji HA, Saleh WMM, Hanoon M, Imad I, Salim Y. Serotyping, virulence gene expression and phenotypic characterization of E. coli $\mathrm{O} 157: \mathrm{H7}$ in colibacillosis affecting buffalo calves in Basra governorate. Iraqi J Vet Sci. 2019;33(2):445-451. DOI: 10.33899/ijvs.2019.163198

8. Haftu R, Taddele H, Gugsa G, Kalayou S. Prevalence, bacterial causes, and antimicrobial susceptibility profile of mastitis isolates from cows in large-scale dairy farms of Northern Ethiopia. Trop Anim Health Prod. 2012;44(7):1765-1771. DOI: 10.1007/s11250-012-0135$\underline{z}$

9. Daly P, Collier T, Doyle S. PCR and ELISA detection of Escherichia coli in milk. Letters in Applied Microbiol. 2002;34(2):222-226. DOI: 10.1046/j.1472-765x.2002.01074.X

10. Amer S, Galvez FLA, Fukuda Y, Tada C, Jimenez IL, Valle WFM, Nakai Y. Prevalence and etiology of mastitis in dairy cattle in El Oro Province, Ecuador. J Vet Med Sci. 2018;80(6):861-868. DOI: 10.1292/jvms.17-0504

11. Gianneechini R, Concha C, Rivero R, Delucci I, Moreno Lopez J. Occurrence of clinical and sub-clinical mastitis in dairy herds in the 
West Littoral Region in Uruguay. Acta Vet Scand. 2002;43(4):221230. DOI: $10.1186 / 1751-0147-43-221$

12. Guimarães JLB, Brito MAVP, Lange CC, Silva R, Ribeiro JB, Mendonca JFM, Souza GU. Estimate of the economic impact of mastitis: A case study in a Holstein dairy herd under tropical conditions. Prev Vet Med. 2017;142:46-50. DOI: 10.1016/j.prevetmed.2017.04.011

13. Seegers H, Fourichon C, Beaudeau F. Production effects related to mastitis and mastitis economics in dairy cattle herds. Vet Res. 2003;34(5):475-491. DOI: 10.1051/vetres:2003027

14. Aldawmy FK, Thwiny HT, Almaali HMA. Epidemiological and molecular study of Rotavirus infection among human and animal in Karbala and Basrah provinces. Iraqi J Vet Sci. 2021;35(2):403-410. DOI: $10.33899 /$ ijvs.2020.126997.1428

15. Reyher KK, Haine D, Dohoo IR, Revie CW. Examining the effect of intramammary infections with minor mastitis pathogens on the acquisition of new intramammary infections with major mastitis pathogens: A systematic review and meta-analysis. J Dairy Sci. 2012;95(11):6483-6502. DOI: 10.3168/jds.2012-5594

16. Gao J, Barkema HW, Zhang L, Liu G, Deng Z, Cai L, Shan R, Zhang S, Zou J, Kastelic P, Han B. Incidence of clinical mastitis and distribution of pathogens on large Chinese dairy farms. J Dairy Sci. 2017;100(6):4797-4806. DOI: 10.3168/jds.2016-12334

17. Oliveira L, Hulland C, Ruegg PL. Characterization of clinical mastitis occurring in cows on 50 large dairy herds in Wisconsin. J Dairy Sci. 2013;96(12):7538-7549. DOI: 10.3168/jds.2012-6078

18. Leimbach A, Poehlein A, Vollmers J, Gorlich D, Daniel R, Dobrindt U. No evidence for a bovine mastitis Escherichia coli pathotype. BMC Genomics. 2017;18(1):359. DOI: 10.1186/s12864-017-3739-x

19. Ahmed IM. Detection of CTX-M gene in extended spectrum $\beta$ lactamases producing Enterobacteriaceae isolated from bovine milk. $\begin{array}{llll}\text { Iraqi J Vet Sci. 2021; 35(2):397-402. DOI: } & \end{array}$ 10.33899/ijvs.2020.126909.1412

20. Ahmed IM, Aldabbagh SY, Jwher DM. Molecular characterization of extended spectrum cephalosporin resistant Escherichia coli isolated from dogs. Iraqi J Vet Sci. 2021;35(3):473-478 DOI: 10.33899/ijvs.2020.127032.1441

21. Abdulrazzaq KM, Owain MS, Majeed HM, Al-Hyani OHH. Molecular detection of rfbO157, shiga toxins and hemolysin genes for Escherichia coli O157: H7 from canine feces in Tikrit and Mosul cities, Iraq. Iraqi J Vet Sci. 2021:35(2):325-329. DOI: 10.33899/ijvs.2020.126831.1392

\section{الصفات الجزيئية والتحليل الوراثي للاثيريشية القولونية المعزولة من حليب الأبقار المصابة لإية التية

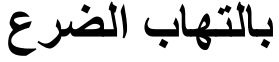

\author{
أزهار عبد السادة نعمة، خلود حمدان فهـ، جنان ناظم صادق و منير \\ عبد الأمير القتلاوي
}

فرع الأحياء المجهرية البيطرية، كلية الطب البيطري، جامعة القادية،

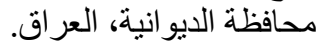

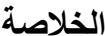

هدفت هذه الدراسة القائمة على التطور إلى تحديد الانتشار الوبائي

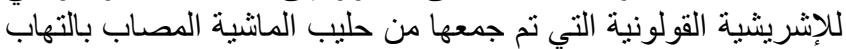

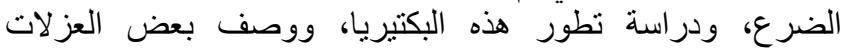

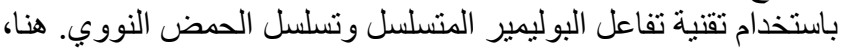

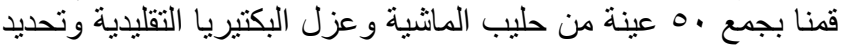

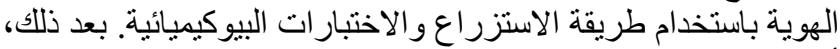

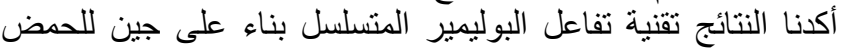

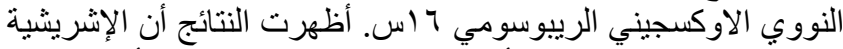

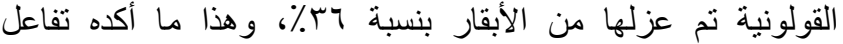

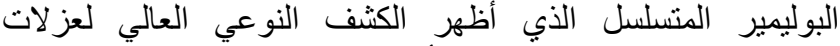

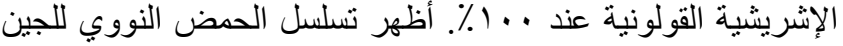

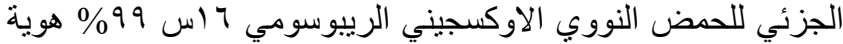

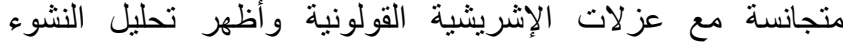

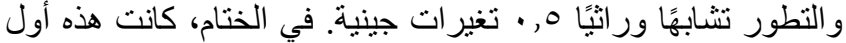

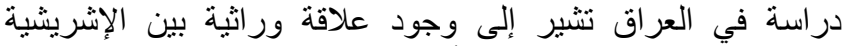

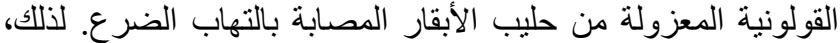

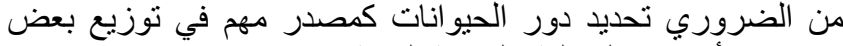
مسببات الأمر اض المتعلقة بالصحة العامة. 